\title{
LEARNING EXPERIENCE FROM TEACHING AND LEARNING METHODS IN ENGINEERING EDUCATION: INSTRUCTORS' VIEWPOINT
}

\author{
D. Hussadintorn Na Ayutthaya1, P. Koomsap', R.M. Lima², T. Nitkiewicz ${ }^{3}$ \\ ${ }^{1}$ Asian Institute of Technology (THAILAND) \\ ${ }^{2}$ University of Minho (PORTUGAL) \\ ${ }^{3}$ Czestochowa University of Technology (POLAND)
}

\begin{abstract}
Knowledge-based learning has been the emphasized pedagogy and balanced with skills-based learning in Engineering education for the last six decades. Students have learned and gained their experiences mainly from lectures, assignments, laboratory sessions, project works, and a final-year project or a dissertation. Besides pedagogy improvement, several teaching and learning methods such as problem-based learning, project-based learning, virtual classroom, etc., have been introduced and applied to offer a variety of learning activities to enhance graduates' competence. This paper presents an analysis of the learning experience that students gain from current teaching and learning methods instructors are using. A survey was conducted on both European and Thai instructors in Industrial Engineering departments and related fields on teaching and learning methods that they normally use and that are effective in their opinion. The survey results were analyzed and mapped on learning experience model called 'LOVE' that classifies learning activities based on the nature of learning and student involvement to draw insight about experience students gain.
\end{abstract}

Keywords: Learning experience, Teaching and learning methods, Instructors' viewpoint, Experience model, LOVE, Quality in engineering education

\section{INTRODUCTION}

Engineering education is a field of knowledge transversally related to the teaching and learning processes necessary for the development of engineering competences at all levels of training, initial, postgraduate and continuing. The research interest in this field has been increasing almost exponentially in the last decades $[1,2]$. The development of this field in the most prestigious schools of engineering [1] aims to develop the teaching of concepts, techniques, competences, and values that graduates will need for their professional activities. Thus, developing this field will contribute for the improvement of the way engineers are able to develop and apply competences from several areas of science and different technologies to solve real problems of the society [3,4].

In recent years, engineering education all around the world is witnessing truly innovative experiences in the way we teach and how we learn. In other words, a model of teaching and learning centered on students, promoting their motivation, participation, reflection, and creativity has received much attention and becomes more preferable to a knowledge-based learning centered on the transfer of knowledge from teacher to students and hoped that they will make the necessary connections to develop their own competences. It is possible to witness a movement of active learning in engineering education [5], engaging self-reflecting engineering students in meaningful experiences, which are relevant from the point of view of them [6-8]. Several works have been reinforcing the importance of this movement towards active learning, due to the positive impact on learning effects $[7,9]$.

It is undeniable that the development of competences is affected by the way a teacher plans and develops the environment and activities of students, and the way it is experienced by the students. It is relevant to understand how engineering teachers develop their instructional methods. Several works have been studying different instructional methods in the higher education context [10-14], but there is a need for a deeper understanding of the main instructional methods used in engineering, for the teachers' beliefs regarding its effectiveness, and for a student learning experience.

This paper aims to make a contribution for a better understanding of the learning experience that students gain from current teaching and learning methods instructors are using in several Thai and European universities. Additionally, this work aims to cross-relate the use of instructional methods with the beliefs the instructors have on the impact they have on learning success. A specific teaching and 
learning method classification, denominated "LOVE", is used as a framework for the analysis of the results. The next section presents the LOVE model and its application for teaching and learning method classification. The research methodology is exemplified in the third section where the research results are also discussed. The conclusion is presented in the last section.

\section{LOVE-BASED TEACHING AND LEARNING METHOD CLASSFICATION}

Influenced by the 4Es model of the progression to experience economy [15], the LOVE model (Fig 1) has been introduced recently to describe learning experience [16]. Based on student involvement (passive or active involvement) and the nature of learning (absorption to immersion), four different types of learning experience have been identified. They are learning $(\mathrm{L})$, observing $(\mathrm{O})$, visiting $(\mathrm{V})$, and experimenting (E). A student becomes a learner when he actively absorbs knowledge provided by an instructor. He becomes an observer when he passively absorbs knowledge provided by an instructor. He becomes a visitor when he passively immerses into a situation to obtain knowledge. He becomes an experimenter when he actively immerses into a situation to obtain knowledge. Learning is to learn, observing is to sense, visiting is to be there, and experimenting is to take action there. The student will gain richest learning experience when the four experiences are offered to him. From being a good observer, learner, visitor, and experimenter, he will become a good researcher, who has indepth knowledge and understanding in a subject.

Recently, the LOVE model has been applied to classify twenty-eight existing teaching and learning methods collected from pieces of literature [17]. As illustrated in Table 1, almost eighty percent of these teaching and learning methods pack on the absorbing nature of learning and the majority are to support the learning group of experience (active absorption). Educators can use this classification to understand current learning experience offering as well as to design new learning experience offering.

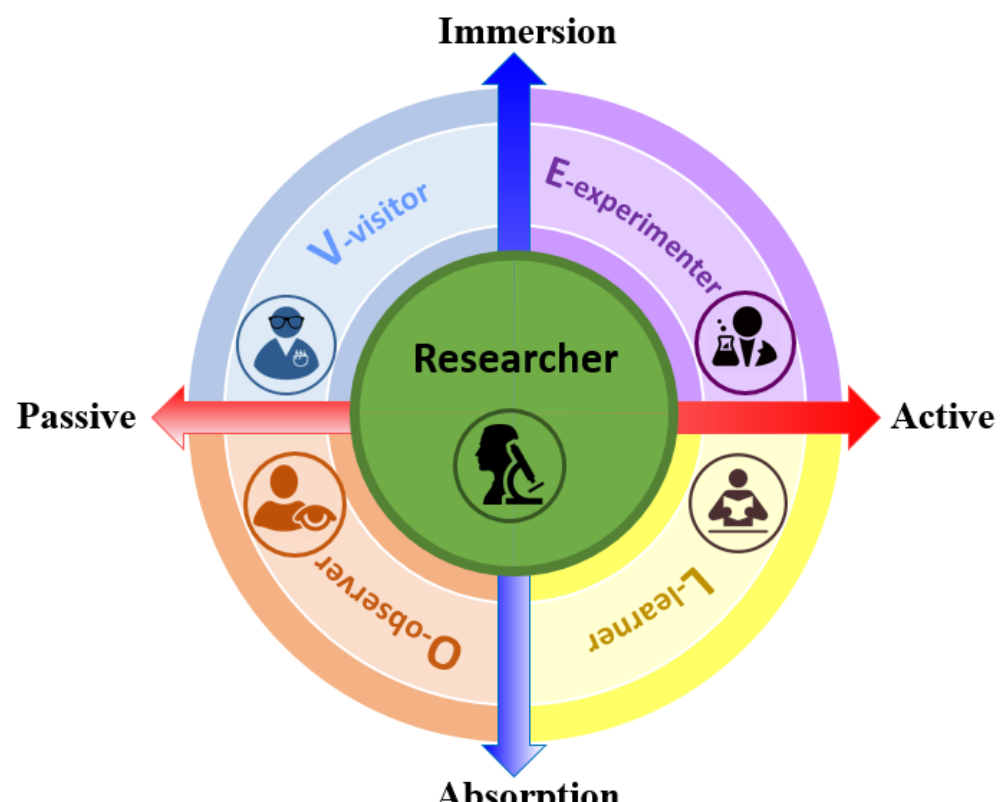

Figure 1. LOVE model [16] 
Table 1. LOVE model and its application on teaching and learning method classification $[16,17]$.

\begin{tabular}{|c|c|c|}
\hline $\begin{array}{l}\text { Type of learning } \\
\text { experience }\end{array}$ & Definition & $\begin{array}{c}\text { Applicable Teaching and Learning } \\
\text { Method }\end{array}$ \\
\hline $\begin{array}{l}\text { L-Learning } \\
\text { (Active } \\
\text { absorption) }\end{array}$ & $\begin{array}{l}\text { As a learner, a student actively } \\
\text { absorbs knowledge and information } \\
\text { provided by an instructor by taking } \\
\text { some actions affected final } \\
\text { outcomes. Examples are a class } \\
\text { presentation and class discussion. }\end{array}$ & $\begin{array}{l}\text { 1. Discussion } \\
\text { 2. Demonstration with exercising } \\
\text { 3. Class debate } \\
\text { 4. Small groups debate } \\
\text { 5. Simulation } \\
\text { 6. Problem-based learning (PrBL) } \\
\text { 7. Programmed teaching } \\
\text { 8. Workshop } \\
\text { 9. Brainstorming } \\
\text { 10. Case study } \\
\text { 11. Online interactive learning } \\
\text { 12. Game-based learning } \\
\text { 13. Guided practical exercises } \\
\text { 14. Role play } \\
\text { 15. Assignments } \\
\text { 16. Individual presentation }\end{array}$ \\
\hline $\begin{array}{l}\text { O-Observing } \\
\text { (Passive } \\
\text { absorption) }\end{array}$ & $\begin{array}{l}\text { As an observer, a student passively } \\
\text { absorbs knowledge and information } \\
\text { provided by an instructor. The } \\
\text { presence of the student does not } \\
\text { affect final outcomes. Attending } \\
\text { lecture and seminar as an audience } \\
\text { is an example of this experience } \\
\text { type. }\end{array}$ & $\begin{array}{l}\text { 1. Lecture } \\
\text { 2. Guided conversation } \\
\text { 3. Integrated or interdisciplinary } \\
\text { teaching } \\
\text { 4. Showing video material } \\
\text { 5. Seminars conducted in classes } \\
\text { 6. Live lecture from a remote place }\end{array}$ \\
\hline $\begin{array}{l}\text { V-Visiting } \\
\text { (Passive } \\
\text { immersion) }\end{array}$ & $\begin{array}{l}\text { As a visitor, a student passively } \\
\text { immerses into a situation to obtain } \\
\text { knowledge and information. The } \\
\text { presence of the student does not } \\
\text { affect final outcomes. An example is } \\
\text { a field trip to an automobile } \\
\text { production company which gives a } \\
\text { real atmosphere of immersion in a } \\
\text { production system to a student. }\end{array}$ & $\begin{array}{l}\text { 1. Field classes, trips and excursions } \\
\text { 2. Conference } \\
\text { 3. Virtual reality }\end{array}$ \\
\hline $\begin{array}{l}\text { E-Experimenting } \\
\text { (Active } \\
\text { immersion) }\end{array}$ & $\begin{array}{l}\text { As an experimenter, a student } \\
\text { actively immerses into a situation to } \\
\text { take action to gain knowledge and } \\
\text { information. The action of the student } \\
\text { influences final outcomes. An } \\
\text { example is a student performs line } \\
\text { balancing analysis at a company. }\end{array}$ & $\begin{array}{l}\text { 1. Project-based learning (PjBL) } \\
\text { 2. Laboratory classes } \\
\text { 3. Virtual laboratory }\end{array}$ \\
\hline
\end{tabular}




\section{RESEARCH METHODOLOGY}

In order to perform an analysis of the learning experience that students gain from the current teaching and learning methods, a questionnaire was created. It composed of three sections: demographic data; the most applied teaching and learning methods; and the most efficient teaching and learning methods. For the most applied teaching and learning methods, participants were asked to share how often they use each of the twenty-eight teaching and learning methods. Choices were have never been applied (0), applied in a very few of the courses (1), applied in some of the courses (2), applied in half of the courses (3), applied in many of the courses (4), and applied in all of the courses (5). For the most efficient teaching and learning methods, they were asked to share their opinions by ranking the top five efficient methods in their viewpoints.

Weighted average and standard deviation were used to represent the most applied teaching and learning methods. A five Likert scale was applied in descending order for weights of the importance of the top five ranking and the sum of products was used for ranking the efficient methods.

\section{RESULTS AND DISCUSSIONS}

\subsection{Survey Results}

The survey was distributed among the members of the partner universities of a funded Erasmus Plus Capacity Building in Higher Education project on "Curriculum Development of Master's Degree Program in Industrial Engineering for Thailand Sustainable Smart Industry (MSIE4.0)". The project consortium comprises of 6 Thai universities and 3 European universities. Forty-two Instructors who are teaching in Industrial Engineering and related fields participated in the survey. According to the respondents, $73.8 \%$ have been teaching for more than 5 years, and $50 \%$ have been teaching for more than a decade. They have offered 4 courses on average. The survey results are available in Table 2.

According to the results, all twenty-eight teaching and learning methods have been applied in practice but at different levels. Lecture is the most popular one. It has been applied in many of the courses (degree of frequency $=4.43$ ) and, at the same time, is perceived as the most efficient method that eases student understanding. Other teaching and learning methods that posed the high frequency of use are in the group of learning experience $(\mathrm{L})$. The instructors interpreted that they have applied five of the methods in this group in half of the courses. They are assignment, case study, guided practical exercises, individual presentation and demonstration with exercising. It is appropriate to notice that they are all conventional methods receiving votes from the instructors for the efficient teaching and learning method. This is a remarkable point that underlines the current trend on the usage and the perception of the conventional teaching and learning methods in engineering education. They are still in the popularity of implementation and being perceived as the efficient methods.

Another interesting point to consider is that project-based learning ( $\mathrm{PjBL}$ )—one of the modern teaching and learning methods - was ranked fourth for the efficient teaching and learning method, but has not yet been exploited much in practice. For the methods that fall into the group of visiting experience $(\mathrm{V})$, they have received very little attention from the instructors in their teaching and perceived as ineffective methods. 
Table 2. Survey results and calculation

\begin{tabular}{|c|c|c|c|c|c|c|c|c|c|c|c|c|c|c|c|c|c|c|}
\hline \multirow{2}{*}{$\stackrel{\text { ֻ }}{\stackrel{\text { }}{\zeta}}$} & \multirow[b]{2}{*}{ Teaching and Learning Method } & \multicolumn{9}{|c|}{ Most Applied Teaching and Learning Method } & \multicolumn{8}{|c|}{ Efficient Teaching and Learning Method } \\
\hline & & 0 & 1 & 2 & 3 & 4 & 5 & Sum & Mean & SD & 5 & 4 & 3 & 2 & 1 & Sum & $\begin{array}{c}\text { Sum } \\
\text { product }\end{array}$ & Rank \\
\hline \multirow{16}{*}{$\mathbf{L}$} & Assignments & 0 & 4 & 8 & 2 & 8 & 20 & 42 & 3.76 & 1.44 & 1 & 7 & 4 & 3 & 2 & 17 & 53.00 & 5 \\
\hline & Case study & 2 & 4 & 8 & 3 & 11 & 14 & 42 & 3.40 & 1.56 & 3 & 2 & 6 & 4 & 4 & 19 & 53.00 & 5 \\
\hline & Guided practical exercises & 2 & 5 & 6 & 4 & 13 & 12 & 42 & 3.36 & 1.54 & 4 & 6 & 6 & 2 & 1 & 19 & 67.00 & 2 \\
\hline & Individual presentation & 3 & 7 & 7 & 3 & 11 & 11 & 42 & 3.07 & 1.67 & 1 & 0 & 1 & 2 & 1 & 5 & 13.00 & 12 \\
\hline & Demonstration with exercising & 2 & 4 & 9 & 9 & 12 & 6 & 42 & 3.02 & 1.37 & 4 & 7 & 2 & 2 & 2 & 17 & 60.00 & 3 \\
\hline & Brainstorming & 3 & 11 & 4 & 8 & 8 & 8 & 42 & 2.74 & 1.63 & 1 & 0 & 0 & 3 & 3 & 7 & 14.00 & 10 \\
\hline & Problem-based learning & 6 & 8 & 6 & 8 & 10 & 4 & 42 & 2.48 & 1.59 & 6 & 2 & 0 & 3 & 4 & 15 & 48.00 & 7 \\
\hline & Discussion & 8 & 8 & 8 & 8 & 5 & 5 & 42 & 2.21 & 1.63 & 1 & 4 & 2 & 3 & 0 & 10 & 33.00 & 8 \\
\hline & Workshop & 9 & 15 & 2 & 8 & 4 & 4 & 42 & 1.88 & 1.62 & 0 & 0 & 3 & 1 & 3 & 7 & 14.00 & 10 \\
\hline & Class debate & 17 & 5 & 6 & 5 & 7 & 2 & 42 & 1.67 & 1.69 & 0 & 0 & 2 & 0 & 0 & 2 & 6.00 & 19 \\
\hline & Small group debate & 14 & 10 & 8 & 4 & 1 & 5 & 42 & 1.60 & 1.63 & 0 & 1 & 1 & 2 & 2 & 6 & 13.00 & 12 \\
\hline & Simulation & 15 & 9 & 7 & 4 & 7 & 0 & 42 & 1.50 & 1.47 & 0 & 0 & 0 & 2 & 0 & 2 & 4.00 & 22 \\
\hline & Game-based learning & 16 & 13 & 6 & 2 & 3 & 2 & 42 & 1.26 & 1.43 & 0 & 2 & 2 & 0 & 1 & 5 & 15.00 & 9 \\
\hline & Role play & 24 & 8 & 4 & 2 & 2 & 2 & 42 & 0.95 & 1.43 & 1 & 0 & 0 & 0 & 0 & 1 & 5.00 & 20 \\
\hline & Programmed teaching & 24 & 7 & 7 & 1 & 2 & 1 & 42 & 0.88 & 1.28 & 0 & 0 & 0 & 0 & 0 & 0 & 0.00 & - \\
\hline & Online interactive learning & 26 & 8 & 3 & 1 & 2 & 2 & 42 & 0.83 & 1.40 & 0 & 0 & 0 & 0 & 0 & 0 & 0.00 & - \\
\hline \multirow{6}{*}{$\mathbf{0}$} & Lecture & 0 & 1 & 5 & 0 & 5 & 31 & 42 & 4.43 & 1.12 & 13 & 3 & 2 & 3 & 5 & 26 & 94.00 & 1 \\
\hline & Showing video material & 5 & 8 & 11 & 8 & 5 & 5 & 42 & 2.36 & 1.51 & 0 & 1 & 2 & 0 & 2 & 5 & 12.00 & 16 \\
\hline & Guided conversation & 11 & 3 & 10 & 1 & 12 & 5 & 42 & 2.36 & 1.80 & 0 & 0 & 2 & 2 & 0 & 4 & 10.00 & 18 \\
\hline & Seminars conducted in class & 7 & 10 & 11 & 4 & 8 & 2 & 42 & 2.05 & 1.48 & 0 & 0 & 0 & 0 & 0 & 0 & 0.00 & - \\
\hline & $\begin{array}{l}\text { Integrated or interdisciplinary } \\
\text { teaching }\end{array}$ & 10 & 8 & 12 & 7 & 5 & 0 & 42 & 1.74 & 1.31 & 0 & 1 & 0 & 3 & 3 & 7 & 13.00 & 12 \\
\hline & Live lecture from a remote place & 34 & 6 & 0 & 1 & 1 & 0 & 42 & 0.31 & 0.80 & 0 & 0 & 0 & 0 & 1 & 1 & 1.00 & 23 \\
\hline \multirow{3}{*}{ V } & Field classes, trips and excursions & 20 & 8 & 9 & 1 & 4 & 0 & 42 & 1.07 & 1.28 & 0 & 1 & 2 & 0 & 2 & 5 & 12.00 & 16 \\
\hline & Conference & 23 & 11 & 4 & 2 & 2 & 0 & 42 & 0.79 & 1.10 & 0 & 0 & 0 & 0 & 0 & 0 & 0.00 & - \\
\hline & Virtual reality & 31 & 4 & 2 & 1 & 4 & 0 & 42 & 0.64 & 1.27 & 0 & 0 & 0 & 0 & 0 & 0 & 0.00 & - \\
\hline \multirow{3}{*}{$\mathbf{E}$} & Project-based learning & 8 & 4 & 8 & 7 & 10 & 5 & 42 & 2.52 & 1.67 & 6 & 4 & 0 & 4 & 0 & 14 & 54.00 & 4 \\
\hline & \begin{tabular}{|l|} 
Laboratory classes \\
\end{tabular} & 18 & 10 & 3 & 5 & 3 & 3 & 42 & 1.38 & 1.62 & 0 & 1 & 3 & 0 & 0 & 4 & 13.00 & 12 \\
\hline & Virtual laboratory & 31 & 4 & 3 & 4 & 0 & 0 & 42 & 0.52 & 0.98 & 1 & 0 & 0 & 0 & 0 & 1 & 5.00 & 20 \\
\hline
\end{tabular}

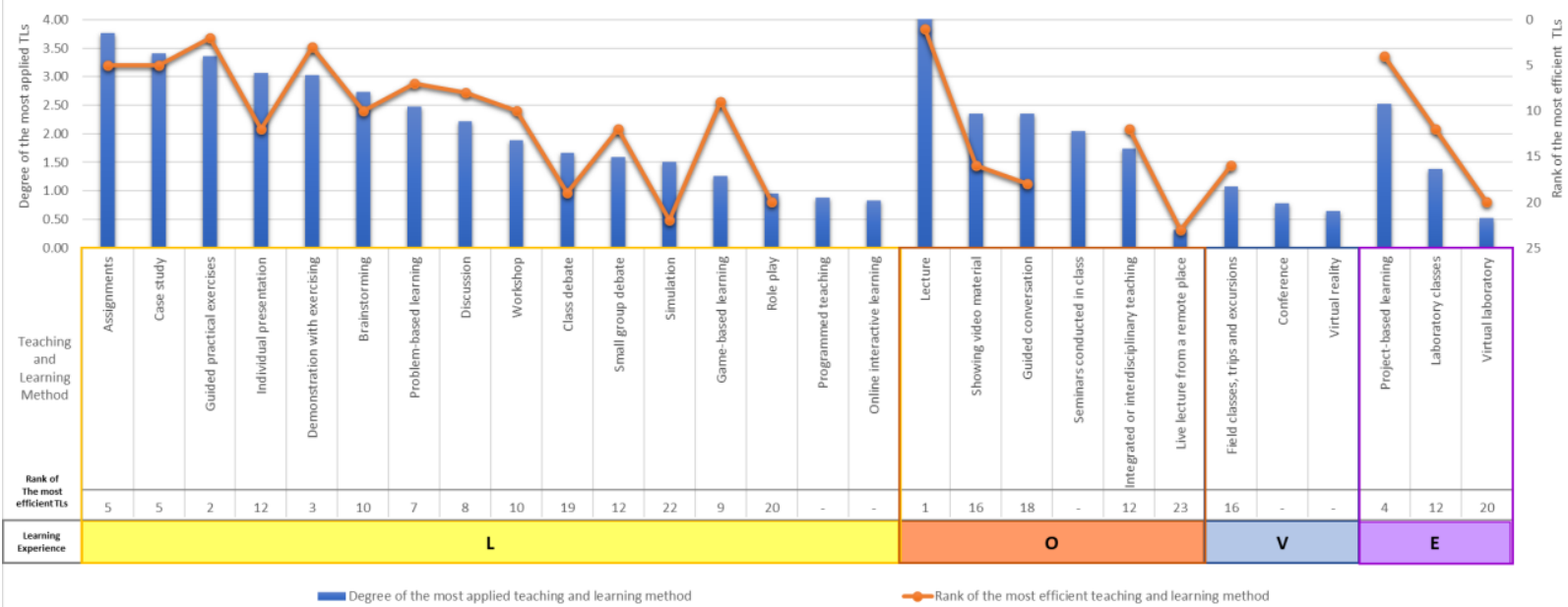

Figure 2. Learning experience from teaching and learning methods in Industrial Engineering Education. 


\subsection{Discussions}

In general, the strong interrelation can be observed between the assessment level of teaching and learning methods and their actual use, especially for the type of methods that induce learning and observing roles for students. The experiment type of experience also has a similar interrelation although its high assessment is significantly less covered in actual use of the methods. No exception could be observed for the visiting type of experiences, but this is probably due to quite small application scale of these methods. Methods in this category of experiences are much different from the others because they usually cannot be provided without the engagement of external actors or have rather an occasional character and do not take much of studying time.

Despite the conformity of application level and efficiency rank, some significant exceptions can also be observed from the general rule. The first type of exception is when a method has a noticeably higher application level than its efficiency rank (e.g., individual presentation and showing video materials). The individual presentation, for instance, is quite commonly used as a teaching method but has a relatively low efficiency rank. No evidence is available for the reasoning behind such an assessment, but this could be due to the outdated approach to run this type of presentations and relative ease in preparing them with almost unlimited access to web resources, and therefore, not very demanding for students. On the opposite scale, the second type is when a method has small coverage in application but relatively higher rank. All the experimenter category methods could be regarded as methods that have much smaller coverage than they deserve.

With more holistic and category oriented look at the expectations lying behind the assessment, the teaching and learning methods can also be classified into the following three categories:

- redefining potential methods - this category would surely include type of learner experience methods that have grounded position in teaching and learning process, but have also outdated approaches and structure; this could be also the case for type of visitor experience methods that have only supportive role in education but could not be replaced by any other methods, and surely have significant role in engineering education,

- growing potential methods - this category would include the type of experimenter experience methods that are expected to have higher coverage but certainly need strategic, program-oriented development path,

- decreasing potential methods - this category would include the type of observer experience methods that seem to have relatively low efficiency on average but still have a significant share in methods portfolio.

According to recent MIT report on engineering education, the problem of current curricula is that the rich in experience methods and courses are often unconnected with other curricular components and these experiences remain unexploited and students are not encouraged to reflect upon and apply what they have learned in other areas of the degree program [18]. This could be the case also for this study, where methods with meaningful experience for the students have relatively low application level, and at some point, are their potential could be lost among other not engaging methods. The classification above is not only the interpretation of current state-of-art with regard to teaching and learning methods in engineering education but also a contribution to formulating its development or rather re-definition strategy.

Furthermore, the discussion of the results should also refer to the teaching and learning context as perceived not only from the perspective of methods but also from other factors that have experience and quality building roles. A more holistic perspective on quality of engineering education has methods and programs at its interest but also considers employees and organization, equipment and infrastructure [19], industry and R\&D partners and networks of relationships, administration and financing possibilities and opportunities [20]. Perhaps, starting development strategy with teaching and learning methods is a good approach, but it would certainly be more efficient with the support in other areas within a more comprehensive program of a change. Current study cannot address this issue right now but it should be noted that internal and external factors could either boost or retard the progress towards meaningful experience. 


\section{CONCLUSIONS}

The LOVE-based teaching and learning method classification was applied in this study to analyze student learning experience from the current practices and instructors' point of view on the efficiency of these teaching and learning methods. The survey was conducted with Thai and European instructors in Industrial Engineering departments and related fields. The strong interrelation can be observed between the assessment level of teaching and learning methods and their actual use, especially for the type of methods that induce learning and observing roles for students. From their opinion, majority of conventional teaching and learning methods are still efficient. Besides projectbased learning that actively immerse students into the subject, the instructors still prefer to transfer knowledge to students and to encourage them participate in the transferring process.

The approach conducted in this research can also be applied in other disciplines for their instructors to understand current student learning experience and properly make an adjustment to make student learning experience richer.

\section{ACKNOWLEDGEMENTS}

This work is the outcome of project "Curriculum Development of Master's Degree Program in Industrial Engineering for Thailand Sustainable Smart Industry (MSIE 4.0)" that has been funded with support from the European Commission (Project Number: 586137-EPP-1-2017-1-TH-EPPKA2-CBHE-JP). This publication reflects the views only of the authors, and the Commission cannot be held responsible for any use which may be made of the information contained therein.

\section{REFERENCES}

[1] R. M. Lima, E. de Graaff, D. Mesquita, \& A. L. Aquere, "Engineering Education (Research) in Higher Education Institutions", Paper presented at PAEE/ALE'2018, 10th International Symposium on Project Approaches in Engineering Education (PAEE) and 15th Active Learning in Engineering Education Workshop (ALE), Brasília, Brazil, pp. 134-140, 2018. Retrieved from http://paee.dps.uminho.pt/proceedingsSCOPUS/PAEE ALE 2018 PROCEEDINGS.pdf

[2] R. M. Lima, \& D. Mesquita, "Engineering Education (Research) in European Countries - an overview based on publications in journals", Paper presented at the 3rd International Conference of the Portuguese Society for Engineering Education (CISPEE 2018), 27-29 June 2018, Aveiro, Portugal, pp. 1-6, 2018.

[3] H.L. Lim, Handbook of Research on Recent Developments in Materials Science and Corrosion Engineering Education: IGI Global, 2015.

[4] UNESCO, Engineering: Issues, Challenges and Opportunities for Development, Accessed 14 January, 2019. Retrieved from http://unesdoc.unesco.org/images/0018/001897/189753e.pdf

[5] R. M. Lima, P. H. Andersson, \& E. Saalman, "Active Learning in Engineering Education: a (re)introduction", European Journal of Engineering Education, vol. 42, no. 1, pp. 1-4, 2017. doi:10.1080/03043797.2016.1254161

[6] C. C. Bonwell, \& J. A. Eison, Active Learning: Creating Excitement in the Classroom, Washington DC: ERIC Clearinghouse on Higher Education, 1991.

[7] M. Prince, "Does Active Learning Work? A review of the Research", Journal of Engineering Education, vol. 93, no. 3, pp. 223-231, 2004.

[8] M. Christie, \& E. de Graaff, "The philosophical and pedagogical underpinnings of Active Learning in Engineering Education", European Journal of Engineering Education, vol. 42, no. 1, pp. 5-16, 2017. doi:10.1080/03043797.2016.1254160

[9] S. Freeman, S. L. Eddy, M. McDonough, M. K. Smith, N. Okoroafor, H. Jordt, \& M. P. Wenderoth, "Active learning increases student performance in science, engineering, and mathematics", Proceedings of the National Academy of Sciences, vol. 111, no. 23, pp. 84108415, 2014. doi:10.1073/pnas.1319030111

[10] L. Andrew, "Comparison of teacher educators' instructional methods with the constructivist ideal”, Teacher Educator, vol. 42, no. 3, pp. 157-184, 2007. doi:10.1080/08878730709555401 
[11] A. F. McKenna, B. Yalvac, \& G. J. Light, "The role of collaborative reflection on shaping engineering faculty teaching approaches", Journal of Engineering Education, vol. 98, no. 1, pp. 17-26, 2009. doi:10.1002/j.2168-9830.2009.tb01002.x

[12] D. B. Friedman, T. B. Crews, J. M. Caicedo, J. C. Besley, J. Weinberg, \& M. L. Freeman, "An exploration into inquiry-based learning by a multidisciplinary group of higher education faculty", Higher Education, vol. 59, no. 6, pp. 765-783, 2010. doi:10.1007/s10734-009-9279-9

[13] S. Neumann, \& R. Koper, "Instructional method classifications lack user language and orientation", Educational Technology and Society, vol. 13, no. 2, pp. 78-89, 2010.

[14] K. J. Herrmann, "The impact of cooperative learning on student engagement: Results from an intervention", Active Learning in Higher Education, vol. 14, no. 3, pp. 175-187, 2013. doi:10.1177/1469787413498035

[15] B. J. Pine, \& J. H. Gilmore, "Welcome to the experience economy", Harvard business review, vol. 76, pp. 97-105, 1998.

[16] D. Hussadintorn Na Ayutthaya, \& P. Koomsap, "Assessment of Student Learning Experience with 'LOVE'”. in Proceedings of INTED2017 Conference 6th-8th March 2017, Valencia, Spain, pp. 1973-1982, 2017.

[17] D. Hussadintorn Na Ayutthaya, \& P. Koomsap, "LOVE-Based Teaching and Learning Method Classification". To be appeared in Proceedings of INTED2019 Conference 11th-13th March 2019, Valencia, Spain, 2019.

[18] R. Graham, The global state of the art in engineering education, MIT School of Engineering, Massachusetts, U.S., 2018.

[19] R. Ulewicz, "Developing a Quality Culture in the Czestochowa University of Technology", in Proceedings of 18th International Symposium on Quality. Quality as a Strategy, 22-24 March 2017, Vodice, Croatia, pp. 267-278, 2017.

[20] T. Nitkiewicz, \& Z. Ayen, "Identifying key criteria in development of Industrial Engineering education", in MATEC Web of Conferences, vol. 183, no. 04008, 2018. Retrieved from http://doi.org/10.1051/matecconf/201818304008 